\title{
Understanding Benign Liquidity Traps: The Case of Japan
}

\author{
Stefan Homburg \\ Hannover Economic Papers (HEP) No. 557 \\ ISSN 0949-9962 \\ First version 12 June 2015 \\ Published: German Economic Review \\ doi:10.1111/geer.12105
}

School of Economics and Management, Leibniz University Hannover, Germany. Phone: +49 511 762-5633. Email: homburg@fiwi.uni-hannover.de.

Abstract: Japan has been in a benign liquidity trap since the 1990s. In a benign liquidity trap, interest rates approach zero and monetary policy is ineffective but output and employment perform decently. Such a pattern contradicts traditional macro theories. This paper introduces a monetary general equilibrium model that is compatible with Japan's performance and resolves puzzles associated with liquidity traps. Possible conclusions for Anglo-Saxon countries and eurozone members are also discussed.

Keywords: Liquidity trap, Japan, interest rate determination, monetary policy, quantitative easing, forward guidance, dynamic general equilibrium, secular stagnation.

JEL-Classification: E31, E43, E52 


\section{Introduction}

The behavior of Japan's economy since the 1990s presents a true challenge for macroeconomics. On the one hand, Japan experienced mild deflation, accompanied by strong declines in asset prices and land values. The absence of inflation over a quarter of a century appears mysterious because Japan is not on the gold standard and its policy makers have made every effort to pull the rate of inflation into positive territory: Quantitative easing was first adopted in Japan, and regarding fiscal policy, the country is also famous for the world's highest debt-to-GDP ratio.

On the other hand, Japan's real indicators, such as output and employment, have performed relatively well. In hindsight, the claim of a "lost two decades" seems exaggerated because Japan's economic record has certainly kept pace with that of other industrialized countries, as will be documented below.

Hence, Japan is in a benign liquidity trap: a state of affairs in which real variables develop reasonably, nominal variables indicate a downturn, and monetary policy fails to operate in the expected manner. These three stylized facts contradict received doctrine. They are inconsistent with models where markets function smoothly, the quantity theory of money is alive and well, and public debt crowds out private investment through higher interest rates. The facts also contradict models that associate deflation with economic depression and unemployment. Economists have sometimes regarded Japan's situation as a mere anomaly. Meanwhile, however, the trap's distinguishing feature-mild deflation in the face of hyper-expansive monetary policy-appears to have spread to other economies, such as the United States, the United Kingdom, and the eurozone.

This paper proposes a monetary dynamic general equilibrium model that reproduces the aforementioned stylized facts and facilitates an analysis of benign liquidity traps. The paper is organized as follows. To motivate the subsequent analysis, section 2 summarizes key figures of Japan's economy and compares them with those of similarly advanced economies. Section 3 presents a monetary general equilibrium model that, depending on the specification, is able to produce all traditional propositions but cannot account for benign liquidity traps. Section 4 augments the model with a credit constraint. This single variation in assumptions has far-reaching consequences and yields features resembling Japan's record. Conclusions for monetary policy are outlined in section 5, which shows that the central bank gains control over nominal and real interest rates in a benign liquidity trap but loses its ability to manage inflation. Section 6 discusses how some of the underlying premises can be relaxed, and section 7 adds concluding remarks.

The idea that credit constraints have striking economic consequences is of course well known. Following Hellwig's (1981) original theoretical treatment, many authors have studied the interaction of credit constraints, collateral requirements, and asset prices. Geanakoplos $(1996,2014)$ considers leverage cycles as self-reinforcing interplays between credit capacities and collateral values. Kiyotaki and Moore (1997) and Sakuragawa and Sakuragawa (2009) examine credit constraints in moneyless 
models, Ogawa and Suzuki (1998) study an interesting partial equilibrium model with such a constraint, and Araújo, Schommer, and Woodford (2015) analyze collateral equilibria in pure exchange economies. Eggertsson and Mehrotra (2014) presented a model of secular stagnation that differs from the present one in two crucial respects: First, the mentioned authors consider credit constraints that restrict household borrowing, whereas this paper concentrates on credit limits for firms. Second, Eggertsson and Mehrotra deal with "real" credit limits in a moneyless economy. By contrast, the present model gives money an explicit role, puts it into the budget constraints and portrays credit constraints as nominal frictions that arise, e.g., from accounting conventions and regulatory requirements.

This paper's objective is not to explain credit constraints, but to trace their macroeconomic consequences in a dynamic model with production, investment, and an explicit monetary sector. This richer setting sheds light on important features of contemporary economies, including the decline in nominal interest rates and the seeming inability of monetary policy to change this course.

\section{Review of the Data}

Japan's recent economic history is well documented, cf. Ueda (2012) and the references cited therein. This brief section concentrates on the point of interest here: Japan's real and monetary performance over the last 25 years, in comparison with the conduct of its fellow industrialized countries.

Table 1 reports average real per capita growth rates and average unemployment rates for France, Germany, Italy, Japan, the United Kingdom, and the United States. In terms of growth, Japan is obviously not an outlier in this group; its growth rate lies between the rates of France and Italy. German growth was somewhat stronger but distorted upward in the initial years of the period as a result of reunification. The United Kingdom and the United States grew somewhat more rapidly.

Table 1: Real economic indicators, 1990-2013.

\begin{tabular}{lcc}
\hline & Per capita growth & Unemployment \\
\hline France & $1.0 \%$ & $10.0 \%$ \\
Germany & $1.3 \%$ & $8.1 \%$ \\
Italy & $0.3 \%$ & $9.2 \%$ \\
Japan & $0.8 \%$ & $4.0 \%$ \\
United Kingdom & $1.6 \%$ & $6.9 \%$ \\
United States & $1.4 \%$ & $6.1 \%$ \\
\hline
\end{tabular}

Note: The table reports growth rates of gross domestic product per capita and unemployment rates, both averaged over the period 1990-2013. Source: OECD database, items B1_GA (gross domestic product), hist5 all ages (population), and harmonized unemployment rate all ages (unemployment), retrieved 15 May 2015. 
Regarding employment, Japan is the distinct leader among the larger advanced economies. Its average unemployment rate was less than one-half that of the continental European countries and less than two-thirds that of the Anglo-Saxon countries. Taken together, the figures do not sustain claims of Japanese economic malaise. Given these undisputable facts, where does the assertion of "two lost decades" stem from, and why are other countries petrified by the prospect of "Japanization"? Two explanations can be offered.

First, some observers confound total growth with per capita growth. With its declining population, Japan cannot reach the same total growth rate as a country such as the United States, where the population is still rising rapidly. To eliminate the resulting bias, elementary theory suggests comparing per capita growth rates. Second, it has often been noted that Japan performed better in the period 1950-1989 than in subsequent years. This is certainly true, yet also explainable in textbook terms. In the period after WWII, Japan began as an emerging economy that gradually caught up with the advanced world. Having reached the technology frontier, it entered a steady state with lower growth. From this perspective, Japan's falling growth rates resemble the experience of similar countries, like Germany or Korea, where phases of rapid growth ended after the countries had caught up with the most prosperous.

Japan's nominal indicators, however, are in fact unique. Although all comparable countries experienced inflation over the last 25 years, Japan's price level actually declined by 11.1 percent, or 0.5 percent annually, with relatively small annual variations. As the data in table 2 show, nominal interest rates were also exceptionally low in Japan, amounting to less than one-half of the levels of the other countries.

Table 2: Monetary economic indicators, 1990-2013.

\begin{tabular}{lcc}
\hline & Inflation & Nominal interest rate \\
\hline France & $1.5 \%$ & $5.2 \%$ \\
Germany & $1.5 \%$ & $4.8 \%$ \\
Italy & $3.1 \%$ & $6.2 \%$ \\
Japan & $-0.5 \%$ & $2.4 \%$ \\
United Kingdom & $2.9 \%$ & $5.7 \%$ \\
United States & $2.1 \%$ & $5.0 \%$ \\
\hline
\end{tabular}

Note: The table reports changes in the GDP deflator and nominal long term interest rates, both averaged over the period 1990-2013. Source: World Bank database, item NY.GDP.DEFL.KD.ZG (inflation) and OECD database, item long-term interest rates, both retrieved 15 May 2015.

Some final observations pertain to monetary policy. After the real estate and stock market crash at the start of the 1990s, Japan's central bank first adopted a passive stance, hoping that the economy would shortly return to normal. This hope faded during the following decade, and after the turn of the century, monetary policy be- 
came more aggressive, commencing with a first round of quantitative easing in 2001-2006 and culminating in the noted "Abenomics", which began after Prime Minister Shinzo Abe won the 2012 elections. Even these exceptional measures, however, have rendered no perceptible effects as yet, and this completes the puzzle that is the subject of this paper: the concurrence of acceptable real development on the one hand, mild deflation and monetary policy ineffectiveness on the other.

\section{Baseline Model}

The baseline model envisions a one-sector economy with a central bank, many identical households, and many identical firms. Time is divided into discrete periods, $t=1,2, \ldots$ The economy could be regarded as an overlapping generations model, but as Bernanke and Gertler (1989: 15) rightly note, there is no need to interpret this model literally. As long as the analysis is confined to qualitative results, the period length is a matter of convention; it may be 30 years or just one year. Interpreted generically, the overlapping time structure does not focus on younger and older persons but represents what is essential for dynamic macro theory: a present, a future, and expectations that guide current action.

There are two distinct assets, interest-bearing bonds and money, which bears no interest. In each period, the central bank creates a money stock, $M_{t}$, by purchasing bonds in the amount of $B_{t}^{c b}>0$. The bonds are redeemed in the following period when they also yield interest, at a nominal rate, $i_{t}$, which is fixed in advance. The central bank's balance sheet and earnings statement take the form

$$
M_{t}=B_{t}^{c b} \quad \text { and } \quad \sigma_{t+1}=i_{t} B_{t}^{c b}
$$

where $\sigma_{t+1}$ denotes seigniorage, the revenue from money creation. Bonds are issued by firms, which use them to finance investment. As the model neglects risky decision- making and agency costs, bond issues may also be interpreted as bank loans; there is no difference between these two forms of financing at the present level of abstraction. Firms take nominal wage rates, $W$, prices levels, $P$, and nominal interest rates, $i$, as given. They maximize expected profits, $\Pi$, by choosing labor demands, $N^{d}$, capital stocks, $K^{d}$, and bond issues, $B^{s}$ :

(2) $\max _{N_{t+1}^{d}, K_{t}^{d}, B_{t}^{s}} \quad \Pi_{t+1}=P_{t+1} F\left(N_{t+1}^{d}, K_{t}^{d}\right)-W_{t+1} N_{t+1}^{d}-\left(1+i_{t}\right) B_{t}^{s} \quad$ s.t. $\quad B_{t}^{s}=P_{t} K_{t}^{d}$.

The gross production function $F$ is smooth, strictly increasing and strictly quasiconcave, displays constant returns to scale, and satisfies the Inada properties. At a profit maximum, the marginal productivity of labor equals the real wage rate, $W_{t+1} / P_{t+1}$. Moreover, the marginal productivity of capital equals the gross real interest rate, $1+r_{t+1}$, which is defined as $1+r_{t+1}=\left(1+i_{t}\right) /\left(1+\pi_{t+1}\right)$, where $1+\pi_{t+1}=P_{t+1} / P_{t}$ denotes expected inflation.

Households supply a constant quantity of labor, $N$, and maximize logarithmic utility subject to two budget constraints: 


$$
\begin{aligned}
& \max _{C_{t}^{1}, C_{t+1}^{2}, B_{t}^{d}, M_{t}^{d}} \ln C_{t}^{1}+\beta \ln C_{t+1}^{2}+\mu \ln \frac{M_{t}^{d}}{P_{t}} \\
& \text { s.t. i) } P_{t} C_{t}^{1}=W_{t} N-B_{t}^{d}-M_{t}^{d}, \\
& \text { ii) } P_{t+1} C_{t+1}^{2}=\left(1+i_{t}\right) B_{t}^{d}+M_{t}^{d}+\Pi_{t+1}+\sigma_{t+1} .
\end{aligned}
$$

According to the first budget constraint, wage income, $W_{t} N$, is used to finance consumption expenditure, $P_{t} C_{t}^{1}$, bond acquisitions, $B_{t}^{d}$, and the formation of money balances, $M_{t}^{d}$. In the next period, consumption expenditure, $P_{t+1} C_{t+1}^{2}$, is financed by bond and money holdings, interest on bonds, profits, and seigniorage.

Combined, formulae (1), (2), and (3) constitute a consensus model that can be run in several modes to represent prevailing macroeconomic doctrines. First, in the smooth mode, there exists a sequence of prices $\left(P_{t}, W_{t}, i_{t}\right)$ such that all markets clear forever:

$$
\begin{gathered}
C_{t}^{1}+C_{t}^{2}+K_{t}^{d}=F\left(N_{t}^{d}, K_{t-1}^{d}\right), \\
N_{t}^{d}=N, \\
B_{t}^{d}+B_{t}^{c b}=B_{t}^{s}, \\
M_{t}^{d}=M_{t} .
\end{gathered}
$$

The variables in (4) are the optimal choices of households and firms, and the resulting competitive equilibrium is subject to the money stocks set by the central bank. It should be emphasized that the nominal interest rate is an endogenous variable in this model, not a policy instrument. In other words, the central bank can influence $i_{t}$ through its open market operations but cannot fix it outright. The nominal interest rate represents a market bond yield rather than an overnight yield such as the federal funds rate, which pertains only to contracts between banks and the central bank but does not affect firms and households. In the smooth mode, discretionary monetary policy is superneutral (Homburg 2015) and not useful.

Second, in the sticky mode, the model can be used to study the consequences of wage and price rigidities. If excessive nominal wage rates produce unemployment, the labor market equation in (4) must be replaced by the inequality $N_{t}^{d}<N$, whereas commodity and bond markets remain in equilibrium. Monetary policy can raise the price level and can also diminish real wages, provided that nominal wages do not rise in proportion; otherwise stagflation will result. An analogous policy effectiveness proposition holds under price level stickiness; to show this formally, one adds a commodity demand constraint to the firms' decision problem and invokes Clower's (1965) dual decision hypothesis.

Third, the model has a bleak mode, associated with saving gluts, secular stagnation, and overaccumulation, as suggested by Bernanke (2005), Summers (2014), or von Weizsäcker (2014). The simplest example is a stationary state with constant prices and quantities, where the utility function and the production function are specified in such a way that the equilibrium real interest rate, $r$, happens to be negative. At 
constant prices, inflation expectations vanish, the nominal interest rate, $i$, equals the real rate, and as the former is negative in equilibrium, the latter should also become negative. However, the above utility specification requires a strictly positive nominal interest rate. Therefore, the real interest rate cannot reach its negative equilibrium level, commodity demand falls short of commodity supply, unemployment results, and the economy enters an indefinite spiral of strong price-wage deflation (which is not counteracted by a real balance effect, as the model contains no outside money). Such a malign liquidity trap can be avoided if the central bank supports an inflation rate exceeding the (absolute value of the) negative real equilibrium interest rate.

All of the preceding modes have one crucial feature in common: They are inconsistent with Japan's situation, which is characterized by high employment, mild deflation, and policy ineffectiveness. The smooth mode exhibits high employment at least, but expansive monetary policy would produce inflation. The sticky mode entails unemployment, effective monetary policy, and possible wage-price inflation, all of which contradict Japan's experience. The bleak mode combines unemployment with strong deflation and hence runs counter in both respects to a state of high employment coupled with an almost stable price level. In summary, traditional macro approaches fail to explain events in Japan. A new approach is needed, which is developed in the next section.

\section{Benign Liquidity Traps}

The baseline model is now run in a fourth, constrained mode, which has as yet received less attention in monetary macroeconomics. Maintaining all previous assumptions, the constrained mode involves changing the model in a single respect: firms can no longer sell as many bonds as they desire at the prevailing interest rate. Rather, their bond supply is bounded from above by a positive number $\bar{B}$ that represents an exogenous credit limit:

$$
B_{t}^{s} \leq \bar{B}
$$

A natural interpretation of this credit constraint is that only a certain amount of bonds qualifies for issuance. Such may be due to a lack of good collateral, to financial regulation, or to a greater risk awareness on the side of the buyers - the notorious "flight to quality". In any case, as indicated in the introduction, the model's purpose is not to derive the credit limit from the underlying economic and legal structure but to study its macroeconomic consequences. Recent research indicates that credit constraints are still relevant for Japan and its relationship banking. This holds particularly for small and medium enterprises that are dependent on local bank credit, see Hoffmann and Okubo (2015). As a final remark, dividing both sides by firms' revenue, the borrowing constraint could also be written as a maximum loan-to-revenue ratio, $B_{t}^{s} /\left(P_{t} Y_{t}^{s}\right) \leq \bar{B} /\left(P_{t} Y_{t}^{s}\right)$, without affecting any of the following results. 
The following analysis considers the long-run impact of a credit limit. In this context, it is appropriate to focus on stationary states and to abstract from short-run price and wage rigidities. For the time being, zero expected inflation and zero expected profits are also assumed. Zero expected inflation is consistent with constant price and wage levels and implies that nominal and real interest rates coincide. These premises suffice to prove the paper's main result.

Theorem: For every stationary equilibrium with unconstrained bond issues $B^{*}$ and for every number $\bar{B} \in\left(0 ; B^{*}\right)$, there exists a corresponding constrained equilibrium where output and employment are unchanged while the price level, the nominal wage rate, and the term $i /(1+i)$ are diminished by the common factor $\bar{B} / B^{*}$.

The proof is relegated to the appendix. Its economic intuition is simple if one considers the two mechanical consequences of a credit limit step by step: First, the limit diminishes the financial system' capability to finance the original capital stock. As a consequence, balance sheets shrink by the factor $\bar{B} / B^{*}$. Investment and commodity demand decline. The emerging price-wage deflation, however, alleviates the limit's impact on real demand and comes to a halt when the price level has fallen in proportion. Subsequently, firms can carry out their original investment plans at reduced prices. Figure 1 illustrates this adjustment process.

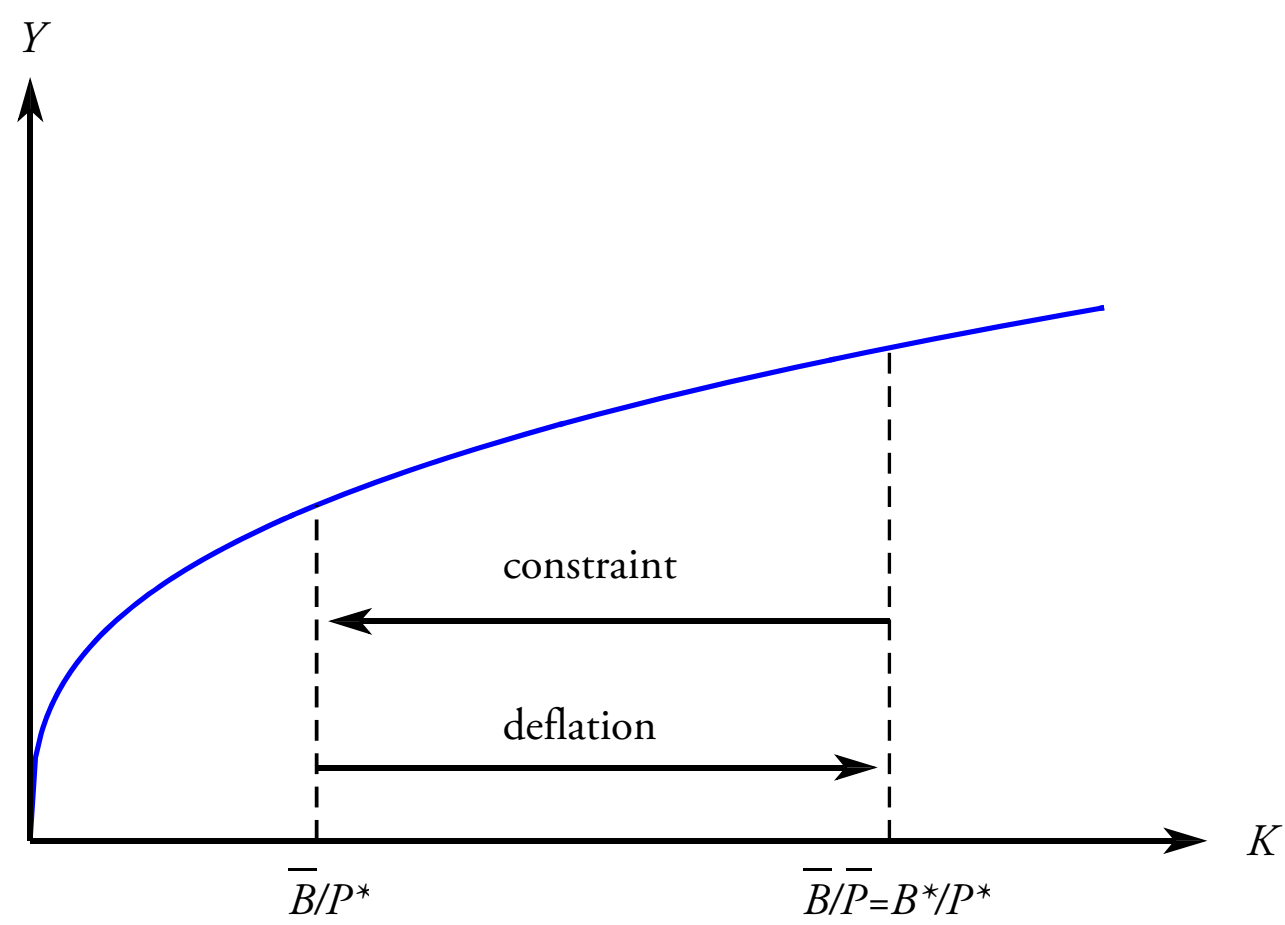

Figure 1: The solid line is the production function. At the original price level, $P^{*}$, the credit constraint reduces the capital stock (leftwards arrow). Deflation relaxes the constraint (rightwards arrow) and restores the original capital stock.

Second, the reduction in bond issues depresses the interest rate. Credit limits make financing harder in terms of credit availability but also easier in terms of credit costs 
(Huggett 1993). Intuitively, households are confronted with a shortage of interestbearing investment opportunities. At the new equilibrium, they hold a smaller nominal amount of bonds but an unchanged nominal amount of money. Such a portfolio is chosen only at a lower interest rate.

The liquidity trap resulting from a credit limit is benign because output and employment remain at their unconstrained equilibrium values-there is no permanent output gap. However, the two equilibria differ in a crucial respect, which is not as obvious: Although firms can finance the unconstrained capital stock, $K^{*}$, in the constrained equilibrium, they are still confronted with a binding credit constraint because the interest rate is now lower. Figure 2 illustrates this central point.

As shown in the appendix, the following relationship between the marginal productivity of capital and the interest rate holds in the case of zero expected inflation:

$$
\frac{\partial F}{\partial K}=1+i+\xi \text {. }
$$

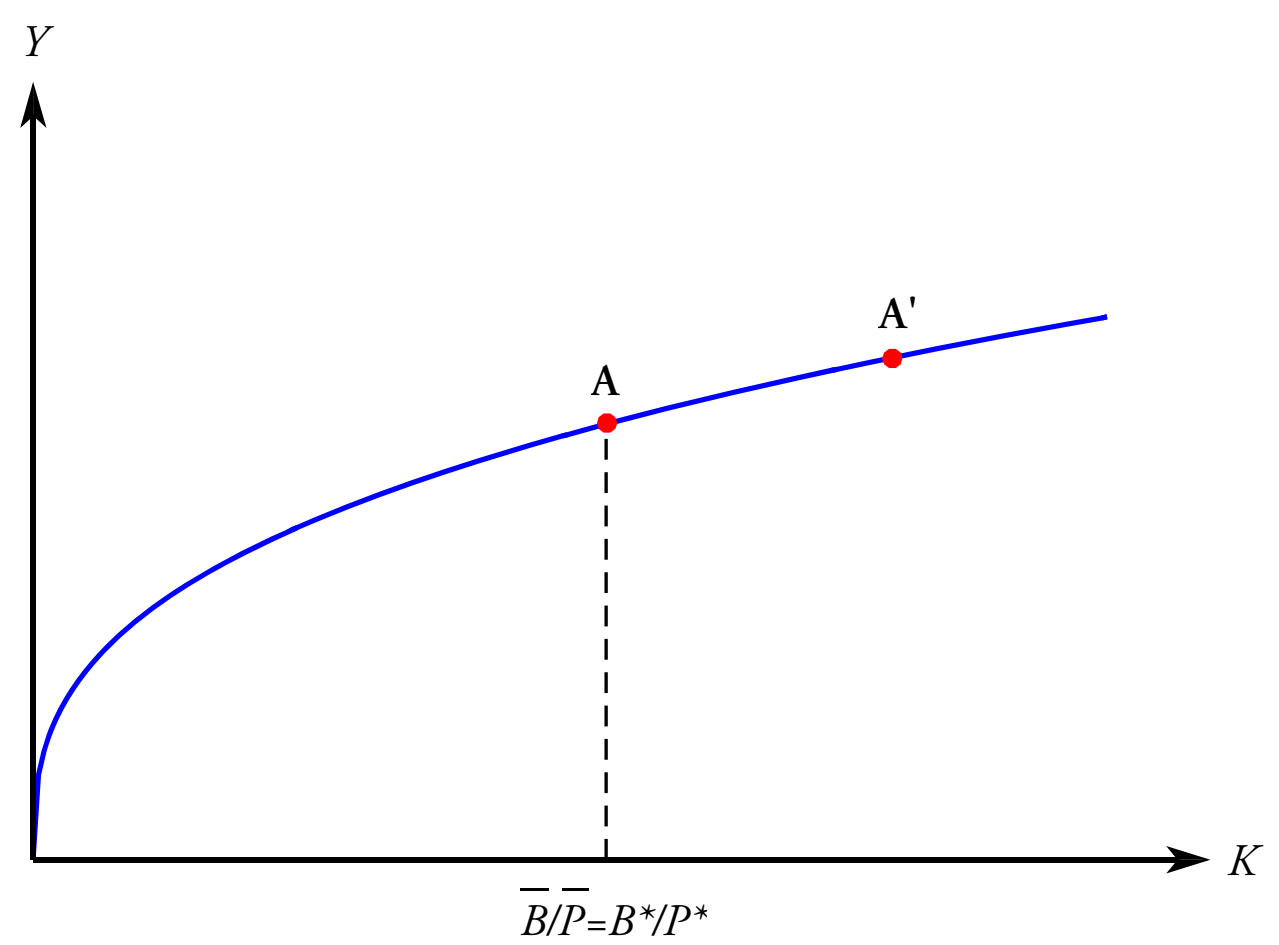

Figure 2: The solid line is the production function. Point A represents the constrained equilibrium. In such an equilibrium, the interest rate is lower than in the unconstrained case. The desired capital stock is higher, such as at point A'.

The Lagrange multiplier $\xi$ represents the shadow price of the credit limit; it reflects the increase in profit following a marginal increase in $\bar{B}$. The formula allows distinguishing two regimes:

- In the unconstrained regime, the shadow price vanishes and the marginal productivity of capital coincides with the gross interest rate, $1+i^{*}$, which equilibrates bond demand and bond supply. 
- In the constrained regime, the shadow price is strictly positive. Therefore, the marginal productivity of capital exceeds the gross interest rate, $1+\bar{i}$, which equilibrates bond demand and the credit limit.

It is common in economics to identify the marginal productivity of capital with the real interest rate; these two terms are used almost interchangeably. Remembering the equality of nominal and real interest rates under zero expected inflation, this identification is unwarranted in the presence of a credit constraint which entails an excess of the marginal productivity of capital over the real interest rate. The positive difference between the marginal productivity of capital and the real interest rate is the key feature of a benign liquidity trap and responsible for many puzzles associated with it. In particular, interest rates become liable to mislead judgments concerning capital costs and dynamic efficiency. For example, if the marginal productivity of capital amounts to $6 \%$ when inflation indexed bonds yield $0.5 \%$, identifying the two magnitudes suggests that the social costs of capital stock reductions are small. It also indicates dynamic inefficiency if the economy grows at a rate of $1 \%$. Both conclusions are false, however, because the marginal productivity of capital exceeds the interest rate. The difference between the two magnitudes represents an equity premium that results from the credit limit alone, without invoking uncertainty (Constantinides, Donaldson, and Mehra 2002).

The preceding analysis may suggest that benign liquidity traps are caused by credit crunches, i.e., sudden decreases in $\bar{B}$. An equally possible cause, however, is a rise in $B^{*}$. Consider the borderline case, $\bar{B}=B^{*}$, where the credit limit equals the unconstrained equilibrium level. If the central bank expands the money supply, the variable $B^{*}$ will rise in proportion and the economy is moved into a constrained equilibrium. Therefore, benign liquidity traps do not presuppose an exogenous fall in the credit limit but can also result from fast monetary expansions combined with credit stickiness.

As a final remark, it should be emphasized again that credit limits have no adverse effects on economic activity if prices and wages are sufficiently flexible. In their account of Japan's experience, Hayashi and Prescott (2002) reject financial explanations, arguing that the output share of investment did not fall during the 1990s. This argument is elusive because it rests on the assumption that credit limits implied just the opposite. In the above model, the output share of gross fixed investment remains constant. Investment falls only in nominal terms but not in real terms.

\section{Monetary Policy}

Traditionally, central banks seek to influence the economy through changes in the overnight interest rate charged to commercial banks. In the late 1990s, this instrument became ineffective in Japan, and the central bank turned to a new policy that is now known as quantitative easing. Quantitative easing involves large bond purchases in the open market and is expected to drive up prices and output via the resulting monetary stimulus. As documented by Japan's recent economic history, the 
new instrument also failed. The following statement, proven in the appendix, shows why.

Corollary 1 (Quantitative Easing): Assume a stationary equilibrium with a binding credit constraint. If the central bank increases the money stock, the nominal interest rate falls, but prices and output remain unchanged.

Central bank bond purchases change the composition of households' portfolios; after the purchase, the portfolios contain more money and fewer bonds. The concurrent decline in the interest rate induces the households to voluntarily retain these new portfolios. However, expansive monetary policy has no further consequences: In particular, it fails to stimulate investment because investment demand is not restrained by credit costs but by credit availability. Therefore, prices and output remain unchanged. Reconsidering figure 2, an expansive monetary policy, which reduces the interest rate, pushes point $A^{\prime}$ to the right. The shadow price of the credit limit rises, and firms would like to increase investment all the more. Yet, they cannot as long as the credit constraint is operative.

Alongside its zero interest policy and quantitative easing, Japan's central bank also employed a third type of policy, known as expectations management or forward guidance, cf. Shirai (2013). Through forward guidance, the central bank attempts to increase inflation expectations in the hope that this will diminish the real interest rate and stimulate aggregate demand. To analyze such a policy, it is necessary to abandon the assumption of zero expected inflation. Clearly, forward guidance is ineffective if it fails to raise inflation expectations. However, it seems instructive to suppose that the central bank can indeed manage expectations and to study the consequences of this hypothesis.

Corollary 2 (Forward Guidance): Assume a stationary equilibrium with a binding credit constraint. If the central bank raises expected inflation from zero to $\pi>0$, the real interest rate falls, but the nominal rate, prices, and output remain unchanged.

This is rather obvious because the marginal productivity of capital exceeds the real interest rate at a constrained equilibrium, cf. (10) in the appendix:

$$
\frac{\partial F}{\partial K}>\frac{1+\bar{i}}{1+\pi}
$$

The right-hand side represents the real interest rate, which will decline if the central bank succeeds in boosting expected inflation. Forward guidance conducted in isolation has no effect on the nominal interest rate that is fixed by households' portfolio choices. If the central bank combines forward guidance with quantitative easing, the concurrent fall in the nominal interest rate (see corollary 1) reinforces the pressure on the real interest rate and may well drive it into negative territory. In any case, the policy fails to have the desired effects because the credit limit, and not the credit costs, presents the true obstacle to higher investment. 
From a theoretical perspective, corollary 2 is the deepest result of this approach. It suggests a reading of the Fisher equation that differs from the standard interpretations:

- According to the prevailing view, the nominal interest rate is jointly determined by expected inflation and the real rate, $1+i=(1+\pi)(1+r)$. This is actually true in the model's smooth mode: the real rate is tied to the marginal productivity of capital, and if expected inflation fluctuates, corresponding adjustments in the nominal rate restore investment demand to its equilibrium level.

- Cashless macro models infer pseudo inflation from $1+\pi=(1+i) /(1+r)$. The real interest rate is tied again to the marginal productivity of capital while the central bank controls the nominal rate as its policy instrument.

- Under a credit constraint, the real interest rate can still be defined through the identity $1+r=(1+i) /(1+\pi)$, where $i$ follows from portfolio equilibrium and $\pi$ represents expected inflation. However, the real rate is a mere residual that ceases to influence economic activity.

Normally, central banks can manage inflation but cannot permanently change the real interest rate. A binding credit constraint turns both inferences upside down: It provides leeway for diminishing the real interest rate through quantitative easing and forward guidance but makes it impossible for the central bank to regulate inflation. These reversed policy effectiveness propositions hold as long as the credit constraint is operative.

To conclude this section, it should be noted that Japan's recent history accords perfectly with the two corollaries. Strong monetary expansion, combined with intense expectations management, has brought the nominal interest rate close to zero and may have driven the real interest rate below zero. Notwithstanding ultra-easy money, real growth remained largely unaffected, and inflation did not show up.

\section{Discussion}

The preceding analysis has made a number of simplifying assumptions. First, zero expected inflation was assumed. Of course, this is the only presumption consistent with a stationary state in which the price level remains constant; nevertheless, the consequences of relaxing the premise should be noted briefly. Positive inflation expectations will not change any of the above results; they only depress the real interest rate, which is of no significance under a credit constraint. Expected deflation is ineffectual up to the point at which the real interest rate equals $r^{*}$, its equilibrium value in the unconstrained case. Beyond that point, strong deflationary expectations could have dire consequences, but such a scenario does not apply to Japan.

Second, the model postulated zero expected profits. In an unconstrained equilibri$\mathrm{um}$, this is perfectly reasonable because factors are paid their marginal products and competition drives down pure profits. In a benign liquidity trap, however, the assumption appears less innocuous. Compared with the unconstrained case, the real 
wage bill is unchanged whereas real interest payments are lower; therefore, actual profits are positive. If individuals did not expect zero profits but anticipated positive profits, they would increase first-period consumption and diminish savings. The same reaction occurred if one replaced logarithmic utility with a utility function implying a positive interest elasticity of savings. Both variations in assumptions would induce a temporary decline in the real capital stock, which suggests that the strict neutrality result of the above proposition should be regarded as a benchmark. However, the two qualifications do by no means entail persistent depression or mass unemployment. In this respect, the key result of a benign liquidity trap remains unimpaired.

Third, positive profits and lower interest rates leave the functional distribution between workers and capitalists unaffected but redistribute capital income from bondholders to stockholders. In the present model, such a redistribution has no further consequence as profits and interest payments are pocketed by the same persons. However, from an empirical perspective, the emerging situation accords well with protests against an alleged exploitation of the ordinary saver. The picture also conforms to the impression of healthy firms, strong stock markets, and persistently high capital costs (see Knolle 2014: 52).

Finally, the nominal credit limit, combined with flexible prices, needs to be discussed. This assumption distinguishes the present approach from papers that use real constraints or sticky prices to arrive at disastrous outcomes that are inconsistent with Japan's record. The premise of a nominal limit is central to the present model and cannot be relaxed without impairing the results. However, the limit may be variable or endogenous. For example, one could consider a time-variant limit, $\bar{B}_{t}$, which follows nominal GDP with a lag. Such a model would produce a sequence of benign liquidity traps, each associated with a lower price level.

\section{Conclusion}

This paper provides a theory that accords with Japan's economic history over the last 25 years. To replicate Japan's performance, the paper introduces a dynamic monetary general equilibrium model with a credit constraint. The constraint drives the economy into a benign liquidity trap in which output and employment perform well.

However, the credit constraint has startling consequences for the properties of the ensuing equilibrium. Most interestingly, financial repression-for which traditional theories do not provide a rationale-becomes possible. Via quantitative easing, central banks can permanently reduce the nominal interest rate without generating inflation. Forward guidance even enables them to push the expected real interest rate into negative territory. Both policy options have the same root: under a binding credit constraint, investment is not restricted by credit costs but by credit availability. Reducing credit costs has no effect on growth and inflation. Moreover, real interest rates underestimate the social costs of capital stock reductions and bias judgments of dynamic efficiency. 
For an extended period, Japan's monetary conduct was unique in the world. Many expected that the country would return to normality at some point, making major revisions of macro textbooks unnecessary. This attitude is beginning to change. In the aftermath of the Great Recession, quantitative easing was adopted by other leading central banks, and again delivered the same disappointing results. More recently, inflation and interest rates shifted toward zero in the eurozone and, to a lesser extent, in the United Kingdom and the United States. This raises the question of whether Japan is an archetype rather than an anomaly.

Although a comprehensive answer to this question is beyond the scope of this paper, an open denial appears difficult. Ultimately, the two Anglo-Saxon countries and the eurozone have imitated Japan's policy approach and have obtained similar results. Specifically, all of these countries have reduced nominal interest rates via unprecedented monetary expansions but still experience price stability. According to the view supported here, a coherent explanation of this concurrence is the existence of a binding credit constraint. This observation, in turn, poses the question of what generates such constraints. Several possible causes come to mind.

Alpanda (2012) and some of the authors cited in the introduction relate credit constraints to a lack of collateral in general and to declining land values in particular. Land and structures constitute by far the most significant collateral in modern economies. A striking feature of Japan's recent history is that nominal land prices have fallen since 1990. As cars, inventory, and the pledgeable share of human capital are less important as collateral, the secular decline in land prices may well be a driving force behind Japan's credit constraint. Financial regulation may also be part of the explanation. It was perhaps no coincidence that the first comprehensive bank regulation, Basel I, became effective in Japan just at the beginning of the 1990s.

At present, Basel III is taking effect and may tighten credit further in coming years. In addition, historic events such as Japan's crash of 1990 or the global financial crisis of 2008 could have changed investors' risk attitudes or risk consciousness. An alternative explanation, however, stems from the observation that benign liquidity traps do not presuppose a sudden decrease in credit limits but can also result from a sudden increase in the equilibrium credit level. Therefore, aggressive monetary policies are apt to move the economy from an unconstrained into a constrained position if the credit limit is unable to adjust quickly enough due to accounting conventions, regulation, or sluggish land prices.

Trespassing the limits of the stylized model studied here, credit constraints accord also with Japan's considerable corporate saving. According to a popular perception, exemplified by Wolf (2013), retained earnings indicate missing investment opportunities. Such a view confuses the two sides of corporate balance sheets: Actually, whether retained earnings are held as idle cash or are invested productively is only indicated by the asset side of the balance sheet, whereas the liability and own equity side, to which retained earnings belong, contains no corresponding information. Under an operative credit constraint, the Modigliani-Miller theorems ceases to hold, and re- 
taining rather than distributing profits is in the shareholders' interest because the internal rate of return exceeds the market interest rate by the constraints' shadow price.

Future research may identify data that allow the researcher to discriminate between the aforementioned possible causes of credit constraints. The purpose of this paper was to stress that such constraints may be more important for macroeconomic performance than are current interest rates. Japan's experience, at least, points strongly in this direction.

\section{Acknowledgements}

I would like to thank participants of the Workshop on Macroeconomics and Business Cycles in Dresden, 2015, participants of the CESifo Area Conference on Macro, Money \& International Finance in Munich, 2016, two anonymous referees, and the editor Mathias Hoffmann for helpful comments.

Address for correspondence: Stefan Homburg, Leibniz Universität Hannover, Königsworther Platz 1, 30167 Hannover, Germany. homburg@fiwi.uni-hannover.de

\section{References}

Alpanda, S. (2012) Taxation, Collateral Use of Land, and Japanese Asset Prices. Empirical Economics 43: 819-850.

Araújo, A., S. Schommer and M. Woodford (2015) Conventional and Unconventional Monetary Policy with Endogenous Collateral Constraints. American Economic Journal: Macroeconomics 7: 1-43.

Bernanke, B. S. (2005) The Global Saving Glut and the U.S. Current Account Deficit. Speech 77, Board of Governors of the Federal Reserve System.

Bernanke, B. S. and M. Gertler (1989) Agency Costs, Net Worth, and Business Fluctuations. American Economic Review 79: 14-31.

Clower, R. W. (1965) The Keynesian Counter-Revolution: A Theoretical Appraisal. In Hahn, F. H. and F. Brechling (eds.) The Theory of Interest Rates. London: Macmillan.

Constantinides, G. M., J. B. Donaldson and R. Mehra (2002) Junior Can't Borrow: A New Perspective on the Equity Premium Puzzle. Quarterly Journal of Economics 117: 269-296.

Eggertsson, G. B. and N. R. Mehrotra (2014) A Model of Secular Stagnation. Cambridge: National Bureau of Economic Research Working Paper No. 20574.

Geanakoplos, J. (1996) Promises Promises. New Haven: Cowles Foundation Discussion Paper No. 1143. 
Geanakoplos, J. (2014) Leverage, Default, and Forgiveness: Lessons from the American and European Crises. Journal of Macroeconomics 39: 313-333.

Hayashi, F. and E. C. Prescott (2002) The 1990s in Japan: A Lost Decade. Review of Economic Dynamics 5: 206-235.

Hellwig, M. F. (1981) Bankruptcy, Limited Liability, and the Modigliani-Miller Theorem. American Economic Review 71: 155-170.

Hoffmann, M. and T. Okubo (2015) 'By a Silken Thread': Regional Banking Integration and Pathways to Financial Development in Japan's Great Recession. Working paper, Zurich University.

Homburg, S. (2015) Superneutrality of Money under Open Market Operations. Hannover Economic Papers (HEP) No. 541.

Huggett, M. (1993) The Risk-Free Rate in Heterogeneous-Agent IncompleteInsurance Economies. Journal of Economic Dynamics and Control 17: 953-969.

Kiyotaki, N. and J. Moore (1997) Credit Cycles. Journal of Political Economy 105: 211-248.

Knolle, J. (2014) An Empirical Comparison of Interest and Growth Rates. MPRA Paper No. 60221.

Ogawa, K. and K. Suzuki (1998) Land Value and Corporate Investment: Evidence from Japanese Panel Data. Journal of the Japanese and International Economies 12: 232-249.

Sakuragawa, M. and Y. Sakuragawa (2009) Land Price, Collateral and Economic Growth. The Japanese Economic Review 60: 473-489.

Shirai, S. (2013) Monetary Policy and Forward Guidance in Japan. Speeches at the International Monetary Fund and the Board of Governors of the Federal Reserve System (mimeo).

Summers, L. H. (2014) U.S. Economic Prospects: Secular Stagnation, Hysteresis, and the Zero Lower Bound. Business Economics 49: 65-73.

Ueda, K. (2012) Deleveraging and Monetary Policy: Japan Since the 1990s and the United States Since 2007. Journal of Economic Perspectives 26: 177-202.

Weizsäcker, C.-C. von (2014) Public Debt and Price Stability. German Economic Review 15: 42-61.

Wolf, M. (2013) Japan's Unfinished Policy Revolution. Financial Times, April $9^{\text {th }}$.

\section{Appendix}

Proof of the Theorem

The theorem asserts the existence of a triple $(\bar{P}, \bar{W}, \bar{i})$ that supports the credit constrained equilibrium and satisfies

$$
\bar{P}=\frac{\bar{B}}{B^{*}} P^{*}, \quad \bar{W}=\frac{\bar{B}}{B^{*}} W^{*}, \quad \frac{\overline{\mathrm{i}}}{1+\overline{\mathrm{i}}}=\frac{\bar{B}}{B^{*}} \frac{\mathrm{i}^{*}}{1+\mathrm{i}^{*}},
$$


where asterisks denote the prices associated with the unconstrained equilibrium. The proof verifies that at the new equilibrium prices, all private agents stick to their original choices, except that nominal bond demand and supply are reduced.

i) To show this for the firms, one forms a Lagrange function from the program (2) and the additional credit constraint (5):

$$
\mathcal{L}=P_{t+1} F\left(N_{t+1}^{d}, K_{t}^{d}\right)-W_{t+1} N_{t+1}^{d}-\left(1+i_{t}\right) P_{t} K_{t}^{d}+\xi_{t}\left(\bar{B}-P_{t} K_{t}^{d}\right) .
$$

Differentiating with respect to the controls yields the following first-order conditions that hold in the stationary state:

$$
\frac{\partial F}{\partial N^{d}}=\frac{W}{P} \text { and } \quad \frac{\partial F}{\partial K^{d}}=\frac{1+i+\xi}{1+\pi}
$$

together with the complementary slackness condition, $\xi\left(\bar{B}-P K^{d}\right)=0$. Financing satisfies $P^{*} K^{*}=B^{*}$ in the unconstrained case and $\bar{P} K^{*}=\bar{B}$ in the constrained case. Hence, it is feasible for firms to maintain their original choice $\left(N^{*}, K^{*}\right)$ at the new price level. Under zero expected inflation, this choice is also optimal for the firms because the real wage rate stays the same while the nominal interest rate is lower. At the original choices, the credit constraint still binds, and its shadow price equals $\xi=i^{*}-\bar{i}>0$. This can be inferred from the equations $\partial F / \partial K=1+\bar{i}+\xi$ and $\partial F / \partial K=1+i^{*}$ because the derivative is evaluated at $\left(N^{*}, K^{*}\right)$ in both cases.

ii) Substituting seigniorage and profit from (1) and (2) into the second-period budget constraint in (3) yields $C^{2}=Y-W N / P$ as ex post second-period consumption in the steady state. Because output, employment, and the real wage rate have already been shown to remain unchanged, second-period consumption also stays the same.

iii) Solving program (3) for zero expected profits (that were assumed in the text and make sense in a competitive framework) and inserting seigniorage from (1) yields explicit demand functions for first-period consumption and money demand in the stationary state:

$$
\begin{aligned}
& C^{1}=\frac{1}{1+\beta+\mu}\left(\frac{W N}{P}+\frac{i}{1+i} \frac{M}{P}\right), \\
& M^{d}=\frac{\mu}{1+\beta+\mu}\left(W N \frac{1+i}{i}+M\right) .
\end{aligned}
$$

Both demands are null homogenous in $(P, W, i /(1+i))$ and hence remain unchanged if the three terms fall by the common factor $\bar{B} / B^{*}$.

iv) It remains to be shown that bond demand equals the credit limit. As prices and wages fall by $\bar{B} / B^{*}$ while employment and first-period consumption remain unchanged, both sides in the budget constraint, $B^{d}+M^{d}=W N-P C^{1}$, are diminished by the factor $\bar{B} / B^{*}$. From the unchanged money equilibrium condition, $M^{d}=M$, and the identity $M=B^{c b}$ it follows that $B^{d}+B^{c b}$ is diminished by the very same factor. Hence, bond demand and bond supply fall by the same amount, which completes the proof. 


\section{Proof of Corollary 1}

Let $\bar{M}$ and $\bar{i}$ denote the money stock and the interest rate prevailing in the initial constrained equilibrium. Multiplying $\bar{M}$ and $(1+\bar{i}) / \bar{i}$ by a constant $m>1$ leaves all feasibility and incentive constraints unchanged, as will be shown below. This implies a reduction in the interest rate.

Considering (10), the decrease in the interest rate does not affect the first-order condition for labor and renders the credit constraint tighter. At the lower interest rate, the capital stock $K^{*}$ is still attainable and optimal for the firms. Following step ii) in the proof of the theorem, second-period consumption will remain unchanged.

From the demand functions (11), one infers that first-period consumption is null homogenous and that money demand is linear homogenous in $(M,(1+i) / i))$. As a consequence, first-period consumption does not change whereas money demand grows in proportion to the money stock. The first-period budget constraint in (3) imply an equivalent reduction in households' bond demand so that total bond demand, $B_{t}^{d}+B_{t}^{c b}$, still coincides with the credit limit. 